IZA DP No. 8227

A Field Study of Chinese Migrant Workers' Attitudes toward Risks, Strategic Uncertainty, and Competitiveness

Li Hao

Daniel Houser

Lei Mao

Marie Claire Villeval

May 2014 


\title{
A Field Study of Chinese Migrant Workers' Attitudes toward Risks, Strategic Uncertainty, and Competitiveness
}

\author{
Li Hao \\ University of Arkansas
}

Daniel Houser

George Mason University

Lei Mao

Université de Lyon, CNRS, GATE

Marie Claire Villeval

Université de Lyon, CNRS, GATE

and IZA

Discussion Paper No. 8227

May 2014

IZA

P.O. Box 7240

53072 Bonn

Germany

Phone: +49-228-3894-0

Fax: $+49-228-3894-180$

E-mail: iza@iza.org

\begin{abstract}
Any opinions expressed here are those of the author(s) and not those of IZA. Research published in this series may include views on policy, but the institute itself takes no institutional policy positions. The IZA research network is committed to the IZA Guiding Principles of Research Integrity.

The Institute for the Study of Labor (IZA) in Bonn is a local and virtual international research center and a place of communication between science, politics and business. IZA is an independent nonprofit organization supported by Deutsche Post Foundation. The center is associated with the University of Bonn and offers a stimulating research environment through its international network, workshops and conferences, data service, project support, research visits and doctoral program. IZA engages in (i) original and internationally competitive research in all fields of labor economics, (ii) development of policy concepts, and (iii) dissemination of research results and concepts to the interested public.
\end{abstract}

IZA Discussion Papers often represent preliminary work and are circulated to encourage discussion. Citation of such a paper should account for its provisional character. A revised version may be available directly from the author. 


\title{
ABSTRACT
}

\section{A Field Study of Chinese Migrant Workers' Attitudes toward Risks, Strategic Uncertainty, and Competitiveness ${ }^{1}$}

\begin{abstract}
Using a field experiment in China, we study whether migration status is correlated with attitudes toward risk, ambiguity, and competitiveness. Our subjects include migrants and non-migrants. We find that, migrants exhibit no differences from non-migrants in risk and ambiguity preferences elicited using pairs of lotteries; however, migrants are significantly more likely to enter competition in the presence of strategic uncertainty when they expect competitive entries from others. Our results suggest that migration may be driven more by a stronger belief in one's ability to succeed in an uncertain and competitive environment than by risk attitudes under state uncertainty.
\end{abstract}

JEL Classification: C93, D03, D63, J61

Keywords: migration, risk preferences, strategic uncertainty, ambiguity, field experiment

Corresponding author:

Li Hao

Sam M. Walton College of Business

University of Arkansas

Fayetteville, AR 72701

USA

E-mail: Ihao@walton.uark.edu

\footnotetext{
${ }^{1}$ We are grateful to participants at the 16th World Congress of International Economic Association in Tsinghua, the Economic Science Association International Meeting at NYU, FUR XV International conference at Georgia State, Chinese Economic Society Meeting in Chengdu, Symposium on Economic Experiments in Developing Countries in Bergen, seminars at Fudan University, Xi'an Jiaotong University, and at GATE for useful comments. This research has been supported by grants from the French National Research Agency (HEIDI grant, ANR-11-EMCO-011) and from the Interdisciplinary Center for Economic Science at George Mason University. It was performed within the framework of the LABEX CORTEX (ANR-11-LABX-0042) of Université de Lyon, within the program "Investissements d'Avenir" (ANR-11-IDEX-007) operated by the French National Research Agency (ANR).
} 


\section{Introduction}

Migration plays a critical role in efficiently re-allocating labor to the place where it is valued the most; migration is the "grease for the wheel of the labor market" (Borjas, 2001). Therefore, it is important to understand migration decisions: what types of people choose to migrate? Are there common characteristics among migrants? The past few decades have witnessed a burgeoning interest in understanding the individual determinants of migration decisions, including expected income differences (Harris and Todaro, 1970; Brucker and Jahn, 2011); rank in the local income distribution (Stark and Taylor, 1991); age and education (Sjaastad, 1962; Schwartz, 1976;

Chiswick, 1986; Malamud and Wozniak, 2012); family and personal networks (Boyd, 1989; Pedersen et al., 2008; Munshi, 2003); concentration of peers in the area of destination (Mora and Taylor, 2005); asymmetric information on skills (Katz and Stark, 1987; Chen, 2005) .

This paper focuses on the relationship between individuals' risk preferences and their migration status. The decision to relocate to a new environment naturally involves uncertainty, e.g., regarding prospects on the labor market, income, housing and lifestyles, especially at the beginning of the relocation. Nonetheless, and although early theoretical literature has recognized its importance (Stark, 1981; Stark and Levarhi, 1982; Katz and Stark, 1986), very few empirical studies on migration have measured the role of individuals' risk preferences (Williams and Balaz, 2012). Moreover, the empirical evidence in the literature has largely relied on census or survey data with self-reported risk preferences that were not elicited in an incentive compatible way (David, 1974; Stark and Levhari, 1982; Guiso and Paiella, 2006; Gibson and 
McKenzie, 2009; Jaeger et al. 2010; Czaika, 2012). For example, Jaeger et al. (2010) used survey data from Germany ${ }^{2}$ to provide evidence that migration propensity is positively associated with willingness to take risks. To the best of our knowledge, we are the first to use an incentivized field experiment to measure risk preferences directly and investigate the relationship between risk preferences and migration propensity. ${ }^{3}$

We conducted our experiment in China, where the current rural-urban labor migration flows are the largest in the history of humanity (Meng et al., 2010). China's transition to a market economy first began in its eastern and southern cities in 1978, while the suppression of labor mobility also gradually lessened (Lin et al., 1998; Zheng et al., 2003). The abundant labor in rural areas ( $80 \%$ of China's population in early 1980 's) began to move to urban areas in search of job opportunities in the rapidly growing manufacturing and service sectors. The scale of migration continued to rise, with the number of migrants surpassing 260 million in the year 2012 alone. $^{4}$ These migrant workers are mainly low skilled; they live in employer-provided dormitories, and save aggressively to support family members back home.

This paper reports data from an artefactual field experiment investigating whether Chinese migrants exhibit attitudes towards risk and uncertainty that differ from their counterparts who did not migrate. Our subjects consist of both migrants and nonmigrants. Migrants are people who work in a county or a city different from the one listed as their domicile residence in the Hukou system (i.e., Household Registration

\footnotetext{
${ }^{2}$ Jaeger et al. (2010) used survey data from the German Socio-Economic Panel (SOEP) where the risk preferences are measured on an eleven-point scale with the question "willingness to take risk in general," with no monetary incentives provided to survey respondents.

${ }^{3}$ More generally, see McKenzie and Yang (2012) on the advantages of using experiments to study migration.

${ }^{4}$ According to the 2012 annual report of migrant workers published by the National Bureau of Statistics of China: http://www.stats.gov.cn/tjfx/jdfx/t20130527 402899251.htm.
} 
System). ${ }^{5}$ Non-migrants, or "stayers," are those who stay in their hometowns. We elicited each subject's preferences under risk and ambiguity, as well as willingness to compete in an environment with strategic uncertainty.

We want to clarify important design features in our experiment.

First, we consider two types of stayers: (i) those in locations where there is little out-migration; and (ii) those in locations where there is substantial out-migration. We hypothesize that these two types of stayers could exhibit different preferences. If migration is indeed a self-selection process in which risk-seeking individuals migrate and risk-averse individuals stay (Umblijs, 2012), then stayers in locations with substantial out-migration are the most risk-averse people in the population, and migrants are the most risk-seeking. These stayers are also possibly less competitive as large-scale migration can "improve" the situation of stayers through less competition for jobs at the local level (Mishra, 2007; McKenzie and Yang, 2012). On the other hand, stayers in locations with little out-migration are still a mixture of risk-seeking and risk-averse individuals. This leads to our prediction regarding the risk preferences of all three groups: stayers in locations with significant out-migration are more riskaverse, followed by stayers in locations with little out-migration; finally, migrants are the most risk-seeking. ${ }^{6}$

Second, we conducted our experiment in both East China and West China, to capture the potential differences across regions. As we discussed earlier, a market

\footnotetext{
${ }^{5}$ This is the generally agreed-upon definition, which is used by the Chinese Census Bureau.

${ }^{6}$ The reason that out-migration occurs in some locations, but not in others, is largely due to historydependence. Chinese migrants rely heavily on their social networks to learn about their job prospects in new locations (see, e.g., Zhao, 2003; Giles, 2006; Chen et al., 2010). As long as the first group of people migrated, people who stayed have better information about migration, which leads to decreased uncertainty. As a result, more migration occurs.
} 
economy was first introduced in East China, and then gradually extended to West China (Lin et al., 1998; Zheng et al., 2003). Hence, East Chinese are more experienced with the market economy, and thus more accustomed to wage and price differences and volatilities. Therefore, we predict that East Chinese are no more riskaverse than West Chinese and this may influence the propensity to migrate.

Third, we distinguish between two different sources of uncertainty: state uncertainty and strategic uncertainty. State uncertainty refers to unknown outcomes, with or without information regarding the probability distributions (Ellsberg, 1961; Fox and Tversky, 1995). Strategic uncertainty, on the other hand, is caused by the purposeful behavior of other players in an interactive decision situation (Brandenburger, 1996). Migration exposes individuals to competition from other migrants and local residents, which involves the strategic element by other decisionmakers. ${ }^{7}$ In our experiment, we use both incentivized lottery choices to elicit risk and ambiguity preferences and a market entry game inspired by Camerer and Lovallo (1999) to elicit willingness to compete, i.e., preference under strategic uncertainty with risk of losses.

Finally, we also included in our experiment a measure for inequality aversion, as income inequality could generate feelings of being relatively deprived or relatively satisfied, both of which may influence individuals' migration decisions (Stark and Bloom, 1985). However, the results are insignificant and so we comment only briefly on this aspect.

\footnotetext{
${ }^{7}$ This is even more the case when countries use visa lotteries to select among applicants (like the U.S. Green Card Lottery) (see examples in McKenzie and Yang, 2012).
} 
Our main findings are that, comparing to stayers, migrants predict significantly higher number of entries from other players, and are also more likely to enter competition despite expecting competitive entries from others. Nonetheless, these populations do not demonstrate differences in risk or ambiguity attitudes under state uncertainty.

Our contributions are twofold. First, we report the first incentivized field experiment investigating the relationship between risk preferences and migration propensities. Second, we are the first to study the impact of different sources of risk and uncertainty, namely, state risk and uncertainty resolved by die rolls and strategic uncertainty due to other people's beliefs and actions. This is important in that the commonly-used incentivized lottery-type elicitation is often found to have quite weak predictive power (Dohmen et al., 2005; 2011). It follows that it is important to examine alternative approaches. In this sense, our paper makes a methodological contribution by studying the differences between migrants' and non-migrants' behavior in ecologically valid market entry games.

Our paper proceeds as follows. Section 2 briefly reviews the related literature. Section 3 describes our experimental design. Section 4 reports our results. Section 5 discusses these results and Section 6 concludes. 


\section{Related Literature}

Our paper contributes to two related literatures. The first is the literature on risk attitudes as a determinant of migration decisions, and the second is the literature on the methodology of eliciting risk attitudes.

In the theoretical literature on the determinants of migrations, Stark (1981) was among the first to recognize risk preferences as a major cause of the migration decision. Stark and Levhari (1982) have shown that risk aversion may explain that rural families in developing countries may push one member to migrate to the urban sector in order to diversity their income portfolio. Katz and Stark (1986) have considered intertemporal risk and uncertainty and demonstrated that migrants may accept an immediate higher risk against the perspective of a great improvement of their future status and a subsequent lower risk. Dustmann (1997) has shown how uncertainty affects the length of migrations and the re-migration decision. In contrast to the previous studies based on the expected utility theory, Czaika (2012) has modeled the migration decision under the prospect theory of Kahneman and Tversky (1979): potential migrants update their expectations about their future prospects when deviating from their reference point and migration flows react more to negative than equivalent positive economic prospects.

The empirical literature on risk attitudes and migrations has developed more recently. An early exception is Sahota (1968) who evokes the higher dynamism and greater tolerance for risk of migrants in Brazil. It is interesting to note that contrary to the early theoretical literature, most empirical studies have identified a negative link between risk aversion and migration propensity. Heitmueller (2005) found that risk- 
averse individuals have a lower propensity to migrate. In a field experiment conducted in Bangladesh, Bryan et al. (2012) found that the migration decision is positively influenced by the provision of insurance in addition to a loan. This is an indirect measure of the impact of risk attitudes. Direct measures include self-reported risk preferences. Many studies have used the data from the German Socio-Economic Panel (SOEP) to study migration propensities. In particular, respondents reported their "willingness to take risks, in general" on a scale from 0 to 10 , where 0 indicates "unwilling to take risks" and 10 indicates "very willing to take risks." Using SOEP data and defining migrants as individuals who changed region at least once between 2000 and 2006, Jaeger et al. (2010) provided the first direct evidence that individuals who are more willing to take risks are more likely to migrate. Constant et al. (2011) found that second generation migrants are more willing to take risks than natives. Finally, Dohmen et al. $(2005 ; 2011)^{8}$ considered self-reported willingness to take risks in specific domains/contexts, such as car driving, financial matters, sports/leisure, career and health. They found that the only risk measure that has predictive power on respondents' decision to move is the global self-assessment of risk. In other words, none of the domain-specific risk measurements are significant at explaining migration decisions. The result holds for migration from East Germany to West Germany, as well as from West to East Germany. Using survey data from three Pacific countries, Gibson and McKenzie (2009) also found that migration propensity is positively associated with willingness to take risks.

\footnotetext{
${ }^{8}$ Dohmen et al. (2005) is the discussion paper version of the published paper Dohmen et al. (2011). The former reports more comprehensive results than the latter. Hence, some of the results we discuss here are only available in Dohmen et al. (2005).
} 
In contrast, Conroy (2009) reported opposing results for Mexico: more risk-averse women are more likely to migrate from countryside to urban areas than less risk-averse women, whereas risk preferences have no predictive power of men's migration decisions. Risk-averse women might use migration as a means to escape from environments with higher income variability.

However, the risk preference measures from survey responses used in these studies were not given any incentives for accurate reporting. In addition to the survey data, Dohmen et al. $(2005 ; 2011)$ also studied the measurement of risk attitudes using incentivized lottery-type elicitation commonly used in experimental research (see e.g., Holt and Laury, 2002; Andersen et al., 2008). Their experiment was conducted in subjects' homes, where subjects first completed the SOEP questionnaire, and then participated in a paid lottery experiment (similar to our risk elicitation under state uncertainty). The authors found that when predicting risk-taking behavior across different domains or contexts (i.e., different sources of uncertainty), global selfassessment of risks is an overall better predictor than risk attitudes elicited using incentivized lotteries. They concluded that risk attitudes do not hold constant across domains. This finding seems to raise questions regarding the validity of the conventional practice of using lottery-type risk elicitations to explain behaviors in other domains.

A potential concern with the use of incentivized lottery-type elicitation methods is a risk of confusion. However, Charness and Viceisza (2011) indicate that both incentivized lottery-type risk elicitation and non-incentivized willingness-to-take-risk scale are at the cost of diminished level of comprehension in the rural developing 
world. They reported a low level of comprehension under both elicitation approaches. Aware of these difficulties, we did our best to facilitate our subjects' understanding of the instructions.

We contribute to this literature by using monetary incentives to provide more accurate measures not only of attitudes towards risk and ambiguity, but also towards strategic uncertainty.

\section{Experimental Procedures and Design}

\subsection{Subjects Recruitment and Experiment Locations}

In this study, migrants are individuals who move from rural to urban areas for work opportunities, and non-migrants are those who stay in their hometown in rural areas. Among non-migrants, we differentiate between those who live in areas with significant out-migrations versus areas with no out-migration. Hence, we study three types of subjects:

1. Migrants who work and live in urban locations,

2. Stayers in rural areas with out-migrations and

3. Stayers in rural areas without out-migrations.

Due to the fact that migrants in cities and comparable stayers in rural areas are not in the same location, it would have been highly impractical to conduct our experiment sessions with mixed types of subjects. Hence, each location in our experiment consisted of a single type. For each type, we had two locations: one in East China, and 
one in West China. Therefore, we had a total of six experiment locations. These locations are described in Table 1 and by the map in Figure $1 .{ }^{9}$

$<$ Insert Table 1 and Figure 1 here $>$

At each location, we conducted two sessions, with 12 subjects per session, and 24 subjects per location. The same group of three experimenters conducted all 12 sessions. As shown in Table 1, migrants were recruited in the cities of Beijing (East) and Chengdu (West). Stayers in rural areas with out-migration were located near Yancheng, Jiangsu (East) and Xianyang, Shaanxi (West). Stayers in rural area with no out-migrations were located near Xuzhou, Jiangsu (East) and Jiuquan, Gansu (West).

We included both an East and a West location for each type of subjects for two reasons: First, to control for the gap in income and economic environments between East and West China. The East coast offers a much greater exposure to marketoriented economic activities as well as higher income than West China. Second, migrating from rural to urban areas within West China has become a new trend, so it is important to include migrants in West China in our study. Historically, the main pattern was migrating from rural inland areas to big cities in East and South China, such as Beijing, Shanghai, and Guangzhou. In recent years, manufacturers have gradually moved their factories from the coast to inland provinces, due to the more abundant, hence cheaper, labor.

Subjects were recruited via flyers in all treatments. In addition, we used door-todoor recruiting with stayers in rural areas, and face-to-face recruitment for migrants living in cities. Potential participants were informed that they had the opportunity to

\footnotetext{
${ }^{9}$ These locations were chosen for two reasons: First, the local migration flow had to satisfy our requirements based on the type of subjects we wanted to recruit. Second, they were local contacts that we could trust.
} 
earn cash if they participated in an experiment at the given location and time. As subjects arrived, they first completed a short survey (see Appendix 1) regarding their migration experience. We used the survey answers to determine whether each respondent qualified for the experiment. To qualify in Beijing and Chengdu as a migrant, one's domicile residence (Hukou) could not be part of the city, and the person must have resided in the city for at least 6 months. In the four rural locations, we required that participants have no migration experience at all.

Qualified subjects were invited to stay and participate in the main experiment that immediately followed the survey. Those who did not qualify received compensation for showing up and responding to the survey. ${ }^{10}$ The qualification criterion was not made common knowledge. Subjects did not know any details about the experiment until the session started. No qualified subjects declined the opportunity to participate in the experiment; nor did anyone quit in the middle of the experiment. The two sessions in each location were conducted immediately back-to-back to minimize communication among subjects about the experiment. A typical session lasted about 90 minutes. Mean earnings for subjects were 29.71 Yuan (about \$4.90) (Standard Deviation=6.82).

\subsection{Experimental Design}

The goal of our experimental design is to investigate whether migrants and stayers exhibit different preferences under state uncertainty and strategic uncertainty. The traditional preference elicitation approach only focuses on state uncertainty resolved

\footnotetext{
${ }^{10}$ Disqualified survey respondents received gift bags that were equivalent to 8 Yuan. The gifts included everyday household items such as toothpaste, laundry detergent, etc. These seemed to be preferred over the small amount of cash. This does not interfere with the fact that subjects who participated in our main experiment received cash payment.
} 
via randomization devices. Here, we broaden the traditional approach by eliciting attitudes towards risk and uncertainty under state uncertainty, as well as willingness to compete in an environment with strategic uncertainty. The strategic element is especially important for migration decisions, because other job seekers' decisions immediately affect the prospect of getting a job in a new location.

Our main experiment includes three components. Part I elicits risk and ambiguity preferences under state uncertainty. Part II elicits attitudes towards inequality. Part III elicits preferences of competitiveness under strategic uncertainty, using a variant of the market entry game in Camerer and Lovallo (1999).

At the beginning of each part, subjects were given very detailed instructions (see Appendix 2). They were also required to complete comprehension tests. They proceeded in the experiment only after demonstrating that they understood the environment. All decisions were made on paper.

\section{Part I: Risk Attitudes under State Uncertainty}

To elicit risk and ambiguity, we used a multiple price list approach following a procedure similar to that of Fox and Tversky (1995). Each subject was presented with a set of choices between two options, A and B, as shown in Table 2 .

$$
<\text { Insert Table } 2 \text { here }>
$$

For risk elicitation, there were a total of 10 decisions, one in each row, as shown in the first 10 rows in Table 2. For example, in the first row, Option A offered a certain payoff of 1 Yuan, while Option B was a lottery that paid 10 Yuan with 50\% chance and 0 otherwise. To facilitate comprehension, we illustrated Option B using an urn with 10 balls, 5 black and 5 white. Subjects were told that if a black ball was drawn 
they would receive 10 Yuan, and if a white ball was drawn they would receive nothing. As the subject moved down the list of 10 decisions, the lottery in Option B remained the same, while the certain payoff in Option A increased by 1 Yuan each row (ending at 10 Yuan).

To elicit preferences under ambiguity, we followed the same procedure with the exception that the composition of the urn (i.e., the probability of winning 10 Yuan in Option B) was unknown to subjects.

After each subject submitted all 20 decisions in Table 2, only one out of the 20 decisions was randomly selected for payment. For this payment-binding decision, if Option A was chosen, the subject received the corresponding cash amount. If Option B was chosen, the subject drew a ball from the corresponding urn and was paid according to its color. Decisions were made at the beginning of the sessions but the random draws and payment were made only at the end of the session to avoid contamination of decisions across games.

\section{Part II: Preference towards Inequality}

To elicit advantageous inequality aversion, we used a procedure inspired by the Modified Dictator Game of Blanco et al. (2011). ${ }^{11}$ In this part, all the subjects made decisions in the role of a dictator, under the veil of ignorance. Each subject chose between two different allocations of income between himself and another player, Option A or Option B, as illustrated in Table 3. For example, in the first row, Option A offered equal earnings of 1 Yuan to both players, while Option B offered the first player an earning of 8 Yuan, and the second player 2 Yuan. As the subject moved

\footnotetext{
${ }^{11}$ We did not elicit disadvantageous inequality aversion because the opportunity to migrate should increase the income gap between migrants and stayers at the benefit of the former, not the latter.
} 
down the rows, the unequal earnings in Option B remained exactly the same, while the equal earnings in Option A increased 1 Yuan per row per player. The first 8 rows are in the gain domain, while the last 8 rows are in the loss domain.

Earnings were calculated as follows. After all 16 decisions were submitted, only one decision was randomly selected for payment. Subjects were randomly matched in pairs, and assigned the role of either Player 1 or Player 2. For each pair, Player 1's choice for this decision was chosen to determine both Player 1 and Player 2's earnings. Subjects did not know whether they were Player 1 or Player 2 before the end of the session.

$<$ Insert Table 3 here $>$

\section{Part III: Competitiveness: Preference under Strategic Uncertainty}

To investigate preferences under strategic uncertainty, we employed a variant of Camerer and Lovallo’s (1999) market entry game. In this game, subjects decided whether to enter a market with limited capacity or stay out. If the subject stayed out, she neither gained nor lost. If she entered, she would either gain or lose, depending on the total number of entrants and her rank among them. In our experiment, the ranks of entrants were determined by a random number generator. All 12 subjects in a session made their entry decisions simultaneously, so subjects had to take into account how many of their fellow participants they thought would enter the market. The fact that other people's decisions could affect one's earnings was the strategic uncertainty.

Before each subject made her entry decision for a given market capacity in a round, they also had to predict how many of the 11 other participants would enter the market in this round. These beliefs indicate whether individuals adjust their behavior 
to their perception of other players' competitiveness. They were incentivized with a simple rule such that the subject earned 2 Yuan if her prediction equaled the actual number of entrants for that round. This was in addition to their earnings from the game.

There were a total of 12 rounds of market entry game; payoffs are illustrated in Table 4. For example, in the first round (the first column in Table 4), the total number of prizes was 4 , and the top 4 entrants earned 9 Yuan each. Any entrant ranked $5^{\text {th }}$ place or lower lost 6 Yuan each. This is in contrast to earning zero if they chose to stay out. If the number of entrants was smaller than the number of prizes, then every entrant won a prize.

$<$ Insert Table 4 here $>$

The number of prizes and payoffs at each rank varied from round to round. In the first 8 rounds, top ranks earned positive amounts that were either the same for all or decreasing with ranks. While the number of the prizes and the amounts changed, the sum of all prizes was always 36 Yuan. Next, the $9^{\text {th }}\left(10^{\text {th }}\right)$ round offered prizes of 6 (12) Yuan to top ranks, and losses of 6 Yuan to bottom ranks, but the total number of prizes was unknown to subjects. Hence, the degrees of ambiguity in rounds 9 and 10 were higher than in the first eight rounds. Up until round 10, staying out always yielded an earning of zero. ${ }^{12}$.

To help make the game easier to understand, we framed the market as a fishing pond, and the total number of prizes was referred to as pond capacity. Subjects did not

\footnotetext{
${ }^{12}$ Rounds 11 and 12 explored the domain of negative earnings to capture attitudes towards losses in the presence of strategic uncertainty. In these rounds, staying out generated a loss of 4 Yuan, while entering and ranking among the top ranks resulted in a loss of less than 4 Yuan. Entering and ranking near the bottom resulted in a loss of 6 Yuan. We do not report the results on the last rounds in this paper.
} 
receive any feedback until all 12 rounds were finished, and they were clearly informed that only one out of all 12 rounds would be randomly selected for payment at the end of the session.

\section{Results}

We first present key demographic characteristics. We then show that migrants and stayers do not exhibit any difference regarding their preferences under state uncertainty. Finally, we investigate their preference under strategy uncertainty using the market entry game. Our main results are that: comparing to stayers in locations with out-migration, (i) migrants predict significantly higher number of entries from other players, and are more willing to enter competition despite expecting competitive entries from others; (ii) stayers in locations with no out-migration also predict higher number of entries, and are more likely to enter competition despite expecting competitive entries from others.

\subsection{Demographic Statistics}

Table 5 summarizes some key demographics variables of the three groups of subjects in our experiment.

$<$ Insert Table 5 here $>$

First, regarding age, migrants were youngest; stayers with no out-migration were older; and stayers with out-migration were the oldest. This is consistent with the observation that younger people migrate, and older people stay in their hometowns. Locations with no out-migration have more balanced age groups, so the average is in 
between. Income is ordered in exactly the opposite direction of subjects' ages, due to the fact that people migrate for better pay in urban areas. In all three groups, we had more men than women. Subjects, on average, were either middle school graduates or high school dropouts who spent 9 to 10 years in school. Naturally, the number of elderly dependents (as grown children in China are expected to support their elderly parents and grandparents) is negatively correlated with subjects' age; it is also positively correlated with their income. Migrants reportedly support more elders on average than stayers, suggesting that greater family responsibility is a major motivation for young people to migrate for job opportunities.

\subsection{Preference regarding Risks, Ambiguity, and Inequality}

In this subsection, we report data on preferences towards risks, ambiguity, and inequality from Parts I and II of the experiment.

In Part I, a rational decision maker should switch at most once from the lottery (Option B) to the certain payoff (Option A) in both the risky and the ambiguous lotteries. The switch points in the two sets of decisions are informative about the individual's attitudes towards risk and uncertainty, respectively. We measure preferences using the number of risky or ambiguous Option B chosen by the subject. ${ }^{13}$

\footnotetext{
${ }^{13}$ Precisely, we take the midpoint of the decision numbers before and after the switch. For example, if a participant switches over to Option A from Option B at Decision \#5, then we record 4.5 as his risk preference. For people who switch back and forth, we count the frequency of the risky option (Option B) chosen, and add 0.5 for the precision adjustment. In fact, 35, 30, 40 and 46 subjects switched more than once in the risk game, the ambiguity game, in the gain domain of the inequality game and in the loss domain of the inequality game, respectively. These values are high, but the frequency of multiple switching does not differ significantly between our groups of subjects (see Table A1 in Appendix 3), and frequent multiple switching is typical of experiments conducted in the field (see notably Charness and Viceisza, 2011).
} 
Option B has an expected payoff of 5 Yuan. Subjects will switch to the "safe" Option A when it is attractive enough. Switching at decision 5 or 6 indicates neutrality; switching earlier (later, respectively) indicates risk aversion (risk loving, respectively). Hence, the number of Option B's indicates a subject's willingness to take risk; the greater this number, the more willing the subject is to take risk.

In Part II, a rational decision maker should also switch at most once from the asymmetric (Option B) to the symmetric allocation (Option A) in the gain domain, and in the other opposite direction in the loss domain. Preferences towards inequality are measured by the number of unequal Option B chosen by the subject. In the gain domain, this indicates the subject's willingness to accept inequality in earnings. In the loss domain, this suggests the willingness to take unequal losses. In both domains, the later the switch, the less inequality averse is the subject.

Figure 2 summarizes the mean and standard errors of the preferences by subject types. The first set of three bars indicates their risk preferences; the next sets of bars are for the attitudes towards ambiguity and towards inequality in the gain and the loss domains. None of the pair-wised comparisons between subject types is significant (mean comparison tests, $p>0.10$ ) (see Table A2 in Appendix 3).

$<$ Insert Figure 2 here $>$

We formally show our first result using regression analysis with control variables shown in Table 6.

Result 1. (Preference under State Uncertainty). Under state uncertainty, migrants and stayers do not exhibit any difference in preferences over risk and ambiguity. 
Support for Result 1. Table 6 reports multivariate regressions with robust standard errors for four dependent variables: subjects' preferences for risk, ambiguity, inequality in the gain domain, and inequality in the loss domain. These preferences are measured as the number of risky (or unequal) options subjects chose. We included a dummy variable Multi-switcher that takes value "one" if the subject switched between risky and safe options (or equal and unequal) more than once, and is zero otherwise. There are two regressions for each preference, where we either do or do not include the variable East, a dummy variable that takes value "one" if the subject was located on the East coast, and is zero otherwise. Our main interests are the coefficients of "Migrant" and "Stayer with no out-migration", which indicate whether these two groups behave different from the omitted category "Stayer with out-migration." Other control variables are gender, age and income.

\section{$<$ Insert Table 6 here $>$}

Regarding preferences towards risk and ambiguity, two results are robust. First, migrants do not differ from stayers with out-migration; second, stayers with no outmigration do not differ from stayers with out-migration. This result is in contrast with the conventional wisdom that migrants tend to be more willing to take risks.

Regressions of inequality in both gain and loss domains are hardly significant at the 5\% level, with F-statistics smaller than 2.50 in all cases. Because conclusions can be misleading if one makes inferences based on insignificant models, the rest of this subsection focuses on preferences regarding risks and ambiguity only.

The control variables, such as gender and age, are significant in the direction we expected (Croson and Gneezy, 2009; Mather et al., 2012). Males are significantly 
more risk/ambiguity-seeking than females, while younger individuals are more risk/ambiguity-seeking than older ones, controlling for migration status. The variable East is worth noting here. In specifications (2) and (4), the regressions of Risk and Ambiguity, adding East significantly improved the regression's goodness-of-fit, as evidenced by the fact the adjusted $\mathrm{R}^{2}$ more than doubled in both cases.

\subsection{Preference regarding Competition under Strategic Uncertainty}

We report in this subsection results from the first eight rounds of the market entry game where all payoffs are positive and the number of prizes is known to subjects. ${ }^{14}$ In these rounds, there are several asymmetric Nash equilibria in pure strategy, under the assumption of risk neutrality. If rational, $c+5$ or $c+6$ decision-makers should enter the market. For $c=2$ and $c=4$, the $c+6^{\text {th }}$ player should be indifferent because his expected payoff from entry is 0 . Above $c+6$ entrants, entering the market leads to negative expected payoffs. For $c=6$ and $c=9$, all the players should enter the market (only the $12^{\text {th }}$ subject should be indifferent when $c=6$ ). A higher expected number of entrants above the market capacity should reduce the entry of risk-neutral individuals (except when $c>4$ ). Naturally, risk and ambiguity aversion should lead players to be indifferent between entering and staying out at lower ranks above the capacity.

Table 7 reports marginal effects of six probit regressions with robust standard errors clustered at the individual level in parentheses. ${ }^{15}$ First, we investigate whether the decision to enter competition is associated with one's migration status. In models

\footnotetext{
${ }^{14}$ Regressions of the last four rounds in the market entry game are not significant; therefore, we do not report those results.

15 Our results remain unchanged using linear probability models clustered at the individual level.
} 
(1) and (2), the dependent variable "entry" is 1 if the subject entered the competition, 0 otherwise. In models (3) and (4), the dependent variable "competitiveness" is 1 if the subject entered the competition after having predicted that the number of entrants was greater than the number of prizes, and 0 otherwise. Models (2) and (4) include only the explanatory variables: migration status (stayers with out-migration are not included and hence the base group for comparison). Models (1) and (3) include control variables such as male, age, income, east, risk preferences (measured by the switching point from the risky to the safe option), and a dummy variable "risk multi-switcher" indicating that the subject did multi-switch at least in the risk preference elicitation. This leads to Result 2.

Result 2a. (Competitiveness). Among those who believe that there are more entrants than prizes, migrants are significantly more likely to enter the market competition than stayers with out-migration.

Result 2b. (Competitiveness). Among those who believe that there are more entrants than prizes, stayers with no out-migration are significantly more likely to enter the market competition than stayers with out-migration.

$<$ Insert Table 7 here $>$

Support for Result 2. Model (2) shows that migrants are 17\% significantly more likely to enter the market than stayers with out-migration. This effect is not significant ( $p$-value $=0.11)$ in model (1) where we include the set of control variables in model. However,, models (3) and (4) show that, robust to including/excluding control variables, migrants who have predicted greater entries than number of prizes are $18 \%$ significantly more likely to enter the competition. These results suggest that migrants 
are more competitive and have greater confidence in their ability to win. Similarly, compared to stayers with out-migration stayers with no out-migration are $13 \%$ more likely to enter the competition and $13 \%$ more likely to compete when they predict a high level of competition to win a prize.

Next, we analyze whether migrants and stayers differ in their predicted competitiveness of others. The dependent variable in models (5) and (6) is "predicted market competitiveness", which is 1 if the subject's predicted number of entrants is greater than the number of prizes for the round, and is 0 otherwise. Our next set results follows.

Result 3a. (Prediction of Market Competition). Migrants are significantly more likely to predict a number of entries in excess of the market capacity than stayers with outmigration.

Result 3b. (Prediction of Market Competition). Stayers with no out-migration are significantly more likely to predict a number of entries in excess of the market capacity than stayers with out-migration.

Support for Result 3. Model (5) shows that, keeping all control variables at their median values, migrants are $20 \%$ more likely to predict market entries of others is in excess of the market capacity than stayers with out-migration. Similarly, stayers with no out-migration are $19 \%$ more likely to predict excess entries than stayers with outmigration. We also observe that those who are more risk-loving under state uncertainty are marginally more likely to expect market competitiveness.

Results (2) and (3) suggest that migrants are not only more competitive; they also expect competitiveness from others. Indeed, they are both more likely to predict the 
competitiveness of others and more likely to enter the competition when they predict a tough competition. ${ }^{16}$

\section{Discussion}

We have investigated preferences between three groups of subjects: migrants, stayers with and without out-migration, considering two sources of uncertainty: state and strategic uncertainty. Two key issues are raised by our investigation.

Two types of stayers. - We use stayers at locations with out-migration as the base group to compare with the other two groups. These stayers are the people who choose not to migrate despite having easier access to information regarding migration (from their migrating neighbors) than stayers in locations where only very few people have migrated. Our results confirm the hypothesis that stayers with out-migration are less willing to enter a competition with strategic uncertainty than stayers without outmigration. In contrast, no difference has been found across groups in attitudes towards risk and ambiguity under state uncertainty.

East China vs. West China. - An interesting and robust finding in our data is that people who reside in East China are significantly more willing to take risks under state uncertainty and they are less inequality averse in the gain domain, regardless of whether they are migrants or local residents. As shown in Tables 6 and 7, the goodness-of-fit of all regression models improves dramatically after including the

\footnotetext{
${ }^{16}$ For a robustness check, we re-do all the regressions from Results 2 and 3, but with a subset of data where pond capacity is either 2 or 4 , which means the number of entrants at equilibrium is smaller than 12. Summarizing Table A3 in Appendix, most results remain qualitatively the same, although stayers with no out-migration no longer differ from the other stayers.
} 
control variable East, indicating the variable's significance in explaining the data. When the economic reform started three decades ago, it was focused in East and South coasts of China (mainly Shanghai and Shengzhen), while the reform occurred at a much slower pace in West China. Therefore, people in East China have been exposed to market economy longer, and more comprehensively. We speculate that people in East China are more used to higher variance in opportunities and wealth, and migrants who moved from inland to East China are self-selected to be similar, or have adapted to the norms. This result is in line with prior findings that economic regime could reshape individuals' preferences (Ockenfels and Weimann, 1999; Alesina and FuchsSchundeln, 2007; Brosig-Koch et al., 2011). Finally, it is important to note that this East-West difference does not change our main findings regarding migrants $v s$. nonmigrants differences as regards strategic uncertainty, as shown in Table 7.

\section{Conclusion}

We conducted the first incentivized field experiment to study whether migration decisions could be explained by risk attitudes, competitiveness, or both. We find that migrants are significantly more willing than non-migrants to enter a competition with strategic uncertainty; in contrast, people from different groups demonstrate identical attitudes towards risk and ambiguity under state uncertainty. ${ }^{17}$

Our contributions are twofold. First, our results contribute to the debate on the relationship between risk preferences and migration propensity. As our results show,

\footnotetext{
${ }^{17}$ We acknowledge that our conclusions are drawn based earnings about half a day to a full day's wage. These are not life-changing stakes, but decent amount of incentives that give us insights about subjects' preferences.
} 
the answer is not straightforward, and depends on how the uncertainty is generated: does it involve other people's decisions? Competing with other participants seems to resonate with migrants well, as they take significantly more risk in this environment than non-migrants when they expect a tough competition, whereas no behavioral difference is found between the two groups when the risks are generated via die rolls. Intuitively, this finding is consistent with the fact that migrants move to urban locations to enter the competition in the labor market.

Second, our results suggest that the conventional methodology of eliciting risk preferences using lists of lotteries is not one-size-fits-all. As a complementary tool, the market entry game used in this paper seems quite suitable when the outcome variables of interest involve human interactions, and especially competition. Our paper takes a first step towards enriching the toolbox of incentivized preference elicitation methods in a way that might be useful for better understanding migration decisions.

With a quarter billion Chinese people migrating from rural to urban areas in the year 2013 alone, there is clearly significant policy importance tied to understanding determinants of migration decisions. Large-scale migration not only provides rich labor resources to businesses in more developed regions, but also ameliorates unemployment and enables rural populations to escape poverty. At the same time, the influx of large migrant populations into cities raises widespread concerns regarding the adequacy of health care, education and housing. An improved understanding of migration decisions, and the preferences of migrants, is a step towards designing policies that enable communities to realize the substantial benefits of migration at minimum social cost. 


\section{References}

Alesina, Alberto and Nicola Fuchs-Schundeln, 2007. "Good-Bye Lenin (or Not?): The Effect of Communism on People's Preferences." American Economic Review, Vol. 97, No. 4, pp. 1507-1528.

Andersen, Steffen, Glenn W. Harrison, Morten I. Lau, and Elisabet E. Rutström, 2008. "Eliciting Risk and Time Preferences." Econometrica, Vol. 76, No. 3, pp. 583-618.

Blanco, Mariana, Dirk Engelmann, Hans Theo Normann, 2011. "A Within-Subject Analysis of Other-Regarding Preferences." Games and Economic Behavior, Vol. 72, No. 2, pp. 321-338.

Borjas, George J. 2001, “Does Immigration Grease the Wheels of the Labor Market?" Brookings Papers on Economic Activity, Vol. 2001, No. 1, pp. 69-119.

Boyd, Monica, 1989. "Family and Personal Networks in International Migration: Recent Developments and New Agendas." International Migration Review, Vol. 23, No. 3, pp. 638-670.

Brandenburger, Adam, 1996. "Strategic and Structural Uncertainty in Games." In Richard Zeckhauser, Ralph Keeney, and James Sebenius (Eds.),Wise Choices: Games, Decisions, and Negotiations. Harvard Business School Press: Boston, pp. 221-232.

Brosig-Koch, Jeannette, Christoph Helbach, Axel Ockenfels and Joachim Weimann, 2011. "Still Different after All These Years: Solidarity Behavior in East and West Germany.” Journal of Public Economics, Vol. 95, No. 11-12, pp. 1373-1376.

Brucker, Herbert and Elke J. Jahn, 2011. "Migration and Wage-Setting: Reassessing the Labor Market Effects of Migration.” Scandinavian Journal of Economics, Vol. 113, No. 2, pp. 286-317.

Bryan, Gharad, Shyamal Chowdhury, and Ahmed Mushfiq Mobarak, 2012. "Seasonal Migration and Risk Aversion.” CEPR Discussion Papers No. 8739.

Camerer, Colin and Dan Lovallo, 1999. "Overconfidence and Excess Entry: An Experimental Approach.” American Economic Review, Vol. 89, No. 1, pp. 306318.

Charness, Gary and Angelino Viceisza, 2011. "Comprehension and Risk Elicitation in the Field: Evidence from Rural Senegal.” IFPRI Discussion Paper No. 01135.

Chen, Yiu Por, 2005. Skill-Sorting, Self-Selectivity, and Immigration Policy Regime Change: Two Surveys of Chinese Graduate Students' Intention to Study Abroad." American Economic Review, Papers and Proceedings, Vol. 95, No. 2, pp. 66-70.

Chen, Yuyu, Ginger Zhe Jin, and Yang Yue, 2010. "Peer Migration in China", NBER Working Paper No. 15671.

Chiswick, Barry R. 1986. "Is the New Immigration Less Skilled Than the Old?" Journal of Labor Economics, Vol. 4, No. 2, pp.168-92. 
Conroy, Hector V., 2009. "Risk Aversion, Income Variability, and Migration in Rural Mexico." California Center for Population Research, UCLA, working draft.

Constant, Amelie F., Annabelle Krause, Ulf Rinne and Klaus F. Zimmermann, 2011. "Economic preferences and attitudes of the unemployed: are natives and second generation migrants alike?” International Journal of Manpower, Vol. 32, No. 7, pp. 825-851.

Croson, Rachel, and Uri Gneezy, 2009. "Gender Differences in Preferences." Journal of Economic Literature, Vol. 47, No. 2, pp. 448-474.

Czaika, Mathias, 2012. "Migrations in times of uncertainty. On the role of economic prospects.” DEMIG Project Paper No. 11, International Migration Institute, University of Oxford.

David, P. A., 1974. "Fortune, Risk and the Microeconomics of Migration" Nations and households in economic growth, New York, NY: Academic Press, pp. 21-88.

Dohmen, Thomas, Armin Falk, David Huffman, Uwe Sunde, Jurgen Schupp and Gert G. Wagner, 2005. "Individual Risk Attitudes: New Evidence from a Large, Representative, Experimentally-Validated Survey." IZA Discussion Paper No. 1730, Bonn.

Dohmen, Thomas, Armin Falk, David Huffman, Uwe Sunde, Jurgen Schupp, and Gert G. Wagner, 2011. "Individual Risk Attitudes: Measurement, Determinants, and Behavioral Consequences." Journal of the European Economic Association, Vol. 9, No. 3, pp. 522-550.

Dustmann, Christian, 1997. Return migration, uncertainty and precautionary savings." Journal of Development Economics, Vol. 52, pp. 295-316.

Ellsberg, Daniel, 1961. "Risk, Ambiguity and the Savage Axioms", The Quarterly Journal of Economics, Vol. 75, No. 4, pp. 643-669.

Fox, Craig R. and Amos Tversky, 1995. "Ambiguity Aversion and Comparative Ignorance." The Quarterly Journal of Economics, Vol. 110, No. 3, pp. 585-603.

Gibson, John and David McKenzie, 2009. "The Microeconomic Determinants of Emigration and Return Migration of the Best and Brightest: Evidence from the Pacific." Journal of Development Economics, Vol. 95, No. 1, pp. 18-29.

Giles, John, 2006. "Is Life More Risky in the open? Household Risk-Coping and the Opening of China's Labor Markets." Journal of Development Economics, Vol. 81, No. 1, pp. 25-60.

Guiso, Luigi, and Monica Paiella, 2006. "The Role of Risk Aversion in Predicting Individual Behavior.” In Pierre-André Chiappori and Christian Gollier (Eds.), Insurance: Theoretical Analysis and Policy Implications. MIT Press: Cambridge.

Harris, John R. and Michael P. Todaro, 1970. "Migration, Unemployment and Development: A Two-Sector Analysis.” American Economic Review, Vol. 60, No. 1, pp. 126-142. 
Heitmueller, Axel, 2005. "Unemployment benefits, risk aversion, and migration incentives." Journal of Population Economics, Vol. 18, pp. 93-112.

Holt, Charles A. and Laury, Susan K., 2002. "Risk Aversion and Incentive Effects." American Economic Review, Vol. 92, No. 5, pp. 1644-1655.

Jaeger, David A., Holger Bonin, Thomas Dohmen, Armin Falk, David Huffman, and Uwe Sunde, 2010. "Direct Evidence on Risk and Migration." Review of Economics and Statistics, Vol. 92, No. 3, pp. 684-689.

Kahneman, Daniel, and Amos Tversky, 1979. "Prospect theory: an analysis of decision under risk.” Econometrica, Vol. 47, pp. 263-291.

Katz, Eliakim, and Oded Stark, 1986. Labor migration and risk aversion in less developed countries." Journal of Labor Economics, No. 4, pp. 134-149.

Katz, Eliakim and Oded Stark, 1987. International migration under asymmetric information." The Economic Journal, Vol. 97, No. 387, pp. 718-726.

Lin, Justin Yifu, Fang Cai, and Zhou Lin, 1998. "Competition, Policy Burdens and State-Owned Enterprise Reform.” American Economic Review, Vol. 88, No. 2, pp. 422-427.

Malamud, Ofer and Abigail Wozniak, 2012. "The Impact of College on Migration Evidence from the Vietnam Generation.” Journal of Human Resources, Vol. 47, No. 4, pp. 913-950.

Mather, Mara, Nina Mazar, Marissa A. Gorlick, Nichole R. Lighthall, Jessica Burgeno, Andrej Schoeke, and Dan Ariely, 2012. "Risk Preferences and Aging: The "Certainty Effect" in Older Adults' Decision Making." Psychology and Aging, Vol. 27, No. 4, pp. 801-816.

McKenzie, David, and Dean Yang, 2012. "Experimental Approaches in Migration Studies.” In Carlos Vargas-Silva (ed.), Handbook of Research Methods In Migration. Edward Elgar: Cheltenham, pp. 249-270.

Meng, Xin, Chris Manning, Shi Li, and Tadjuddin Nur Effendi (Eds.), 2010. The Great Migration. Rural-Urban Migration in china and Indonesia. Edward Elgar: Cheltenham.

Mishra, Prachi, 2007. "Emigration and Wages in Source Countries: Evidence from Mexico." Journal of Development Economics, No. 82, pp. 180-199.

Mora, Jorge and J. Edward Taylor, 2005. Determinants of Migration, Destination and Sector Choice: Disentangling Individual, Household and Community Effects. In Ça-glar Özden and Maurice Schiff (Eds.), International Migration, Remittances, and the Brain Drain. New-York: Palgrave Macmillan, pp. 21-52.

Munshi, Kaivan, 2003. "Networks In The Modern Economy: Mexican Migrants In The U.S. Labor Market.” The Quarterly Journal of Economics, Vol. 118, No. 2, pp. 549-599. 
Ockenfels, Axel and Joachim Weimann, 1999. "Types and Patterns: an Experimental East-West-German Comparison of Cooperation and Solidarity." Journal of Public Economics, Vol. 71, No. 2, pp. 275-287.

Pedersen, Peder J., Mariola Pytlikova and Nina Smith, 2008. "Selection or Network Effects? Migration Flows into 27 OECD Countries, 1990-2000." European Economic Review, Vol. 52, No. 7, pp. 1160-1186.

Sahota, Gian S., 1968. "An Econometric Analysis of Internal Migration in Brazil." Journal of Political Economy, Vol. 76, No. 2, pp. 218-245.

Stark, Oded, 1981. "On the Optimal Choice of Capital Intensity in LDCs with Migration." Journal of Development Economics, Vol. 9, No. 1, pp. 31-41.

Stark, Oded and David E. Bloom, 1985. "The New Economics of Labor Migration." American Economic Review, Vol. 75, No. 2, pp. 173-78.

Stark, Oded and David Levhari, 1982. "On Migration and Risk in LDCs." Economic Development and Culture Change, Vol. 31, No. 1, pp. 191-196.

Schwartz, Aba, 1976. "Migration, Age and Education." Journal of Political Economy, Vol. 84, No. 4, pp. 701-720.

Stark, Oded and J. Edward Taylor, 1991. "Migration Incentives, Migration Types: The Role of Relative Deprivation.” Economic Journal, Vol. 101, pp. 1163-1178.

Sjaastad, Larry A. 1962. "The Costs and Returns of Human Migration." Journal of Political Economy, Vol. 70, No. 5, pp. 80-93.

Umblijs, Janis, 2012, "The Effect of Networks and Risk Attitudes on the Dynamics of Migration.” International Migration Institute Working Paper.

Williams, Allan M., and Vladimir Baláž, 2012. "Migration, risk and uncertainty: theoretical perspectives." Population, Space and Place, Vol. 18, No. 2, pp. 167180.

Zhao, Yaohui, 2003, "The Role of Migrant Networks in Labor Migration: the Case of China." Contemporary Economic Policy, Vol. 21, No. 4, pp. 500-511.

Zheng, Jinghai, Xiaoxuan Liu and Arne Bigsten, 2003. "Efficiency, Technical Progress and Best Practice in Chinese State Enterprises (1984-1994)." Journal of Comparative Economics, Vol. 31, pp. 134-52. 
Table 1. Number of Sessions and Subjects at Each Location

\begin{tabular}{|c|c|c|c|c|}
\hline Subjects type & $\begin{array}{c}\text { Location } \\
\text { West China }\end{array}$ & $\begin{array}{l}\text { Location } \\
\text { East China }\end{array}$ & $\begin{array}{c}\text { \# of } \\
\text { sessions }\end{array}$ & $\begin{array}{c}\text { \# of } \\
\text { subjects }\end{array}$ \\
\hline Migrants & Chengdu & Beijing & 4 & 48 \\
\hline Stayers with Out-migration & Xianyang & Yancheng & 4 & 48 \\
\hline Stayers with No Out-migration & Jiuquan & Xuzhou & 4 & 48 \\
\hline Total number of subjects & 72 & 72 & & 144 \\
\hline
\end{tabular}

Table 2: Risk and Ambiguity Elicitation

\begin{tabular}{|c|c|c|}
\hline Risk: & $\begin{array}{c}\text { Option A } \\
\text { Certain payoff in Yuan }\end{array}$ & $\begin{array}{c}\text { Option B } \\
10 \text { balls in an urn, } 5 \text { blue and } 5 \text { yellow; } \\
\text { Blue pays } 10 \text { Yuan, Yellow pays } 0 .\end{array}$ \\
\hline Decision 1: & 1 & \multirow{10}{*}{ (10 Yuan, 50\%; 0, 50\%) } \\
\hline Decision 2: & 2 & \\
\hline Decision 3: & 3 & \\
\hline Decision 4: & 4 & \\
\hline Decision 5: & 5 & \\
\hline Decision 6: & 6 & \\
\hline Decision 7: & 7 & \\
\hline Decision 8: & 8 & \\
\hline Decision 9: & 9 & \\
\hline Decision 10: & 10 & \\
\hline Ambiguity: & & $\begin{array}{l}10 \text { balls in an urn, unknown blue or yellow; } \\
\text { Blue pays } 10 \text { Yuan, Yellow pays } 0 .\end{array}$ \\
\hline Decision 11: & 1 & \multirow{10}{*}{10 Yuan or 0 ; unknown probability } \\
\hline Decision 12: & 2 & \\
\hline Decision 13: & 3 & \\
\hline Decision 14: & 4 & \\
\hline Decision 15: & 5 & \\
\hline Decision 16: & 6 & \\
\hline Decision 17: & 7 & \\
\hline Decision 18: & 8 & \\
\hline Decision 19: & 9 & \\
\hline Decision 20: & 10 & \\
\hline
\end{tabular}


Table 3: Inequality Elicitation

\begin{tabular}{|c|c|c|}
\hline & $\begin{array}{c}\text { Option A } \\
\text { Equal earnings for Players } \mathrm{X} \text { and } \mathrm{Y} \\
\end{array}$ & $\begin{array}{c}\text { Option B } \\
\text { Unequal earnings for Players } \mathrm{X} \text { and } \mathrm{Y} \\
\end{array}$ \\
\hline \multicolumn{3}{|l|}{ Gain Domain } \\
\hline Decision 1: & $\mathrm{X}$ earns 1 ; $\mathrm{Y}$ earns 1 & \multirow{8}{*}{$\mathrm{X}$ earns $8 ; \mathrm{Y}$ earns 2} \\
\hline Decision 2: & $\mathrm{X}$ earns $2 ; \mathrm{Y}$ earns 2 & \\
\hline Decision 3: & $\mathrm{X}$ earns 3 ; $\mathrm{Y}$ earns 3 & \\
\hline Decision 4: & $\mathrm{X}$ earns $4 ; \mathrm{Y}$ earns 4 & \\
\hline Decision 5: & $\mathrm{X}$ earns 5 ; Y earns 5 & \\
\hline Decision 6: & $\mathrm{X}$ earns 6 ; $\mathrm{Y}$ earns 6 & \\
\hline Decision 7: & $\mathrm{X}$ earns $7 ; \mathrm{Y}$ earns 7 & \\
\hline Decision 8: & $\mathrm{X}$ earns 8 ; $\mathrm{Y}$ earns 8 & \\
\hline \multicolumn{3}{|l|}{ Loss Domain } \\
\hline Decision 1: & $\mathrm{X}$ loses $1 ; \mathrm{Y}$ loses 1 & \multirow{8}{*}{$\mathrm{X}$ loses $8 ; \mathrm{Y}$ loses 2} \\
\hline Decision 2: & $\mathrm{X}$ loses $2 ; \mathrm{Y}$ loses 2 & \\
\hline Decision 3: & $\mathrm{X}$ loses 3 ; Y loses 3 & \\
\hline Decision 4: & $\mathrm{X}$ loses $4 ; \mathrm{Y}$ loses 4 & \\
\hline Decision 5: & $\mathrm{X}$ loses $5 ; \mathrm{Y}$ loses 5 & \\
\hline Decision 6: & $\mathrm{X}$ loses $6 ; \mathrm{Y}$ loses 6 & \\
\hline Decision 7: & $\mathrm{X}$ loses $7 ; \mathrm{Y}$ loses 7 & \\
\hline Decision 8: & $\mathrm{X}$ loses $8 ; \mathrm{Y}$ loses 8 & \\
\hline
\end{tabular}

Table 4: Payoffs in Market Entry Game

\begin{tabular}{|c|c|c|c|c|c|c|c|c|c|c|c|c|}
\hline \multirow[b]{2}{*}{ Rank } & \multicolumn{8}{|c|}{ Gain domain } & \multicolumn{2}{|c|}{ Ambiguity } & \multicolumn{2}{|c|}{ Loss domain } \\
\hline & $\begin{array}{l}\text { R.1 } \\
c=4\end{array}$ & $\begin{array}{l}\text { R.2 } \\
c=9\end{array}$ & $\begin{array}{l}\text { R.3 } \\
c=2\end{array}$ & $\begin{array}{l}\text { R.4 } \\
c=9\end{array}$ & $\begin{array}{l}\text { R.5 } \\
c=2 \\
\end{array}$ & $\begin{array}{l}\text { R.6 } \\
c=6\end{array}$ & $\begin{array}{l}\text { R.7 } \\
c=6\end{array}$ & $\begin{array}{l}\mathrm{R} .8 \\
c=4\end{array}$ & $\begin{array}{l}\text { R.9 } \\
c=\text { ? }\end{array}$ & $\begin{array}{l}\text { R.10 } \\
c=?\end{array}$ & $\begin{array}{c}\text { R.11 } \\
-\end{array}$ & $\begin{array}{c}\text { R.12 } \\
- \\
\end{array}$ \\
\hline 1 & +9 & +8 & +18 & +4 & +27 & +12 & +6 & +18 & +6 & +12 & -1 & -3 \\
\hline 2 & +9 & +7 & +18 & +4 & +9 & +9 & +6 & +12 & $?$ & $?$ & -2 & -3 \\
\hline 3 & +9 & +6 & -6 & +4 & -6 & +7 & +6 & +4 & $?$ & $?$ & -3 & -3 \\
\hline 4 & +9 & +5 & -6 & +4 & -6 & +4 & +6 & +2 & $?$ & $?$ & -6 & -3 \\
\hline 5 & -6 & +4 & -6 & +4 & -6 & +3 & +6 & -6 & ? & ? & -6 & -6 \\
\hline 6 & -6 & +2 & -6 & +4 & -6 & +1 & +6 & -6 & $?$ & $?$ & -6 & -6 \\
\hline 7 & -6 & +2 & -6 & +4 & -6 & -6 & -6 & -6 & $?$ & $?$ & -6 & -6 \\
\hline 8 & -6 & +1 & -6 & +4 & -6 & -6 & -6 & -6 & $?$ & $?$ & -6 & -6 \\
\hline 9 & -6 & +1 & -6 & +4 & -6 & -6 & -6 & -6 & $?$ & $?$ & -6 & -6 \\
\hline 10 & -6 & -6 & -6 & -6 & -6 & -6 & -6 & -6 & $?$ & $?$ & -6 & -6 \\
\hline 11 & -6 & -6 & -6 & -6 & -6 & -6 & -6 & -6 & $?$ & ? & -6 & -6 \\
\hline 12 & -6 & -6 & -6 & -6 & -6 & -6 & -6 & -6 & -6 & -6 & -6 & -6 \\
\hline Stay ou & & & & & 0 & & & & & & & \\
\hline
\end{tabular}


Table 5: Demographic Statistics

\begin{tabular}{lccc}
\hline Status & Migrants & $\begin{array}{c}\text { Stayers with no out- } \\
\text { migration }\end{array}$ & $\begin{array}{c}\text { Stayers with out- } \\
\text { migration }\end{array}$ \\
\hline Age & 32.2 & 37.3 & 45.12 \\
Income/day (Yuan) & $(1.73)$ & $(1.62)$ & $(2.26)$ \\
Male & 62.4 & 40.4 & 28.4 \\
& $(10.3)$ & $(3.80)$ & $(3.80)$ \\
Education & 0.60 & 0.51 & 0.75 \\
& $(0.07)$ & $(0.07)$ & $(.06)$ \\
Elderly dependents & 9.8 & 8.5 & 10 \\
\hline Observations & $(0.31)$ & $(0.31)$ & 1.36 \\
& 2.27 & 2.02 & $(0.20)$ \\
\hline
\end{tabular}

Notes: Means are reported. Standard errors are reported in parentheses. $* 10 \%$ significance level; $* * 5 \%$, and $* * * 1 \%$. 
Table 6: Determinants of the Preferences under State Uncertainty

\begin{tabular}{|c|c|c|c|c|c|c|c|c|}
\hline & \multicolumn{2}{|c|}{ Risk } & \multicolumn{2}{|c|}{ Ambiguity } & \multicolumn{2}{|c|}{ Inequality Gain } & \multicolumn{2}{|c|}{ Inequality Loss } \\
\hline & (1) & (2) & (3) & (4) & (5) & (6) & (7) & (8) \\
\hline \multirow{2}{*}{ Migrant } & -0.895 & -0.985 & -0.978 & -1.074 & $-1.238 * *$ & $-1.292 * *$ & 0.070 & 0.036 \\
\hline & $(0.645)$ & $(0.616)$ & $(0.680)$ & $(0.667)$ & $(0.508)$ & $(0.510)$ & $(0.519)$ & $(0.524)$ \\
\hline \multirow{2}{*}{$\begin{array}{l}\text { Stayer w. } \\
\text { no out- } \\
\text { migration }\end{array}$} & -0.147 & -0.260 & -0.025 & -0.153 & -0.485 & -0.553 & -0.015 & -0.056 \\
\hline & $(0.655)$ & $(0.632)$ & $(0.694)$ & $(0.667)$ & $(0.499)$ & $(0.500)$ & $(0.443)$ & $(0.448)$ \\
\hline \multirow{2}{*}{ Male } & $1.389^{*}$ & $1.323^{*}$ & $1.102 * *$ & $1.009 * *$ & 0.569 & 0.536 & 0.211 & 0.189 \\
\hline & $(0.471)$ & $(0.455)$ & $(0.504)$ & $(0.483)$ & $(0.407)$ & $(0.392)$ & $(0.405)$ & $(0.394)$ \\
\hline \multirow{2}{*}{ Age } & $-0.044^{*}$ & $-0.050 *$ & $-0.030 *$ & $-0.037 * *$ & $-0.027 *$ & $-0.030 *$ & 0.004 & 0.002 \\
\hline & $(0.016)$ & $(0.016)$ & $(0.018)$ & $(0.017)$ & $(0.016)$ & $(0.015)$ & $(0.015)$ & $(0.015)$ \\
\hline \multirow{2}{*}{ Income } & $0.006^{*}$ & 0.004 & $0.009 *$ & 0.007 & 0.004 & 0.003 & -0.000 & -0.001 \\
\hline & $(0.003)$ & $(0.003)$ & $(0.005)$ & $(0.004)$ & $(0.003)$ & $(0.003)$ & $(0.002)$ & $(0.003)$ \\
\hline \multirow{2}{*}{$\begin{array}{l}\text { Multi- } \\
\text { switcher }\end{array}$} & 0.654 & 0.579 & 0.484 & 0.509 & -0.312 & -0.308 & -0.053 & -0.060 \\
\hline & $(0.399)$ & $(0.419)$ & $(0.392)$ & $(0.414)$ & $(0.371)$ & $(0.377)$ & $(0.345)$ & $(0.341)$ \\
\hline \multirow{2}{*}{ East } & & $1.432 *$ & & $1.663^{*}$ & & $0.839 * *$ & & 0.501 \\
\hline & & $(0.434)$ & & $(0.454)$ & & $(0.384)$ & & $(0.348)$ \\
\hline \multirow{2}{*}{ Intercept } & $5.856^{*}$ & $5.609 *$ & $5.127^{*}$ & $4.818^{*}$ & $6.038^{*}$ & $5.883 *$ & $4.358^{*}$ & $4.269^{*}$ \\
\hline & (1.013) & (1.005) & (1.081) & (1.100) & $(0.746)$ & $(0.770)$ & $(0.745)$ & $(0.775)$ \\
\hline $\mathrm{R}^{2}$ & 0.123 & 0.194 & 0.0963 & 0.187 & 0.0761 & 0.111 & 0.00432 & 0.0199 \\
\hline F & 4.123 & 5.779 & 2.691 & 5.037 & 2.015 & 2.403 & 0.110 & 0.347 \\
\hline $\mathrm{Nb}$ of obs. & \multicolumn{2}{|c|}{131} & \multicolumn{2}{|c|}{129} & \multicolumn{2}{|c|}{131} & \multicolumn{2}{|c|}{131} \\
\hline
\end{tabular}

Notes: OLS regressions with heteroskedasticity-robust standard errors reported in parentheses. Regressions of "Ambiguity" have two fewer observations due to missing observations in some of the regressors. * is $10 \%$ significance level; $* *$ is $5 \%$, and $* * * 1 \%$. 
Table 7: Determinants of the Probability of Entry, Competitiveness and Predicted Competitiveness of Others in the Market Entry Game

\begin{tabular}{|c|c|c|c|c|c|c|}
\hline & \multicolumn{2}{|c|}{ Entry } & \multicolumn{2}{|c|}{ Competitiveness } & \multicolumn{2}{|c|}{$\begin{array}{c}\text { Predicted Competitiveness o } \\
\text { Others }\end{array}$} \\
\hline & (1) & (2) & (3) & (4) & (5) & (6) \\
\hline \multirow{2}{*}{ Migrant } & 0.143 & $0.168^{* *}$ & $0.192 * *$ & $0.181^{*}$ & $0.199 * *$ & $0.159^{* *}$ \\
\hline & $(0.089)$ & $(0.080)$ & $(0.084)$ & $(0.066)$ & $(0.088)$ & $(0.073)$ \\
\hline \multirow{2}{*}{$\begin{array}{l}\text { Stayer w. no } \\
\text { out-migration }\end{array}$} & $0.136^{*}$ & $0.132 *$ & $0.127^{*}$ & $0.128^{* *}$ & $0.188^{*}$ & $0.172^{* *}$ \\
\hline & $(0.079)$ & $(0.074)$ & $(0.068)$ & $(0.062)$ & $(0.070)$ & $(0.068)$ \\
\hline \multirow{2}{*}{ Male } & 0.104 & & -0.025 & & -0.041 & \\
\hline & $(0.077)$ & & $(0.062)$ & & $(0.071)$ & \\
\hline \multirow{2}{*}{ Age } & -0.001 & & 0.001 & & 0.001 & \\
\hline & $(0.003)$ & & $(0.003)$ & & $(0.003)$ & \\
\hline \multirow{2}{*}{ Income } & 0.002 & & 0.000 & & -0.001 & \\
\hline & $(0.001)$ & & $(0.001)$ & & $(0.001)$ & \\
\hline \multirow{2}{*}{ Risk } & 0.006 & & $0.018^{*}$ & & $0.030^{*}$ & \\
\hline & $(0.014)$ & & $(0.010)$ & & $(0.011)$ & \\
\hline \multirow{2}{*}{$\begin{array}{l}\text { Risk Multi- } \\
\text { switcher }\end{array}$} & $-0.118^{*}$ & & $-0.145^{* *}$ & & -0.070 & \\
\hline & $(0.065)$ & & $(0.066)$ & & $(0.064)$ & \\
\hline \multirow[t]{2}{*}{ East } & -0.053 & & -0.039 & & -0.039 & \\
\hline & $(0.063)$ & & $(0.053)$ & & $(0.058)$ & \\
\hline Observations & 1031 & 1039 & 1032 & 1040 & 1032 & 1040 \\
\hline Clusters & 129 & 130 & 129 & 130 & 129 & 130 \\
\hline Pseudo $\mathrm{R}^{2}$ & .0433 & .0153 & .0505 & .0257 & .0398 & .0189 \\
\hline
\end{tabular}

Notes: These regressions only consider decisions and beliefs in the first eight rounds of the fishing game. Estimates are from Probit regressions clustered at the individual level, with marginal effects reported as point estimates, and fully robust standard errors reported in parentheses. * is $10 \%$ significance level; $* *$ is $5 \%$, and $* * * 1 \%$. 
Figure 1. Experiment Locations

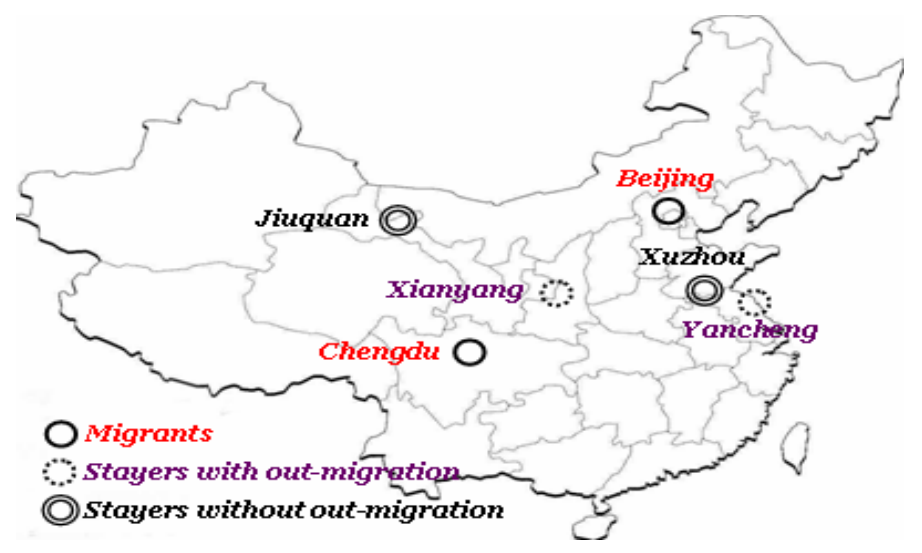

Figure 2. Preferences for Risk, Ambiguity and Inequality, by Migration Status

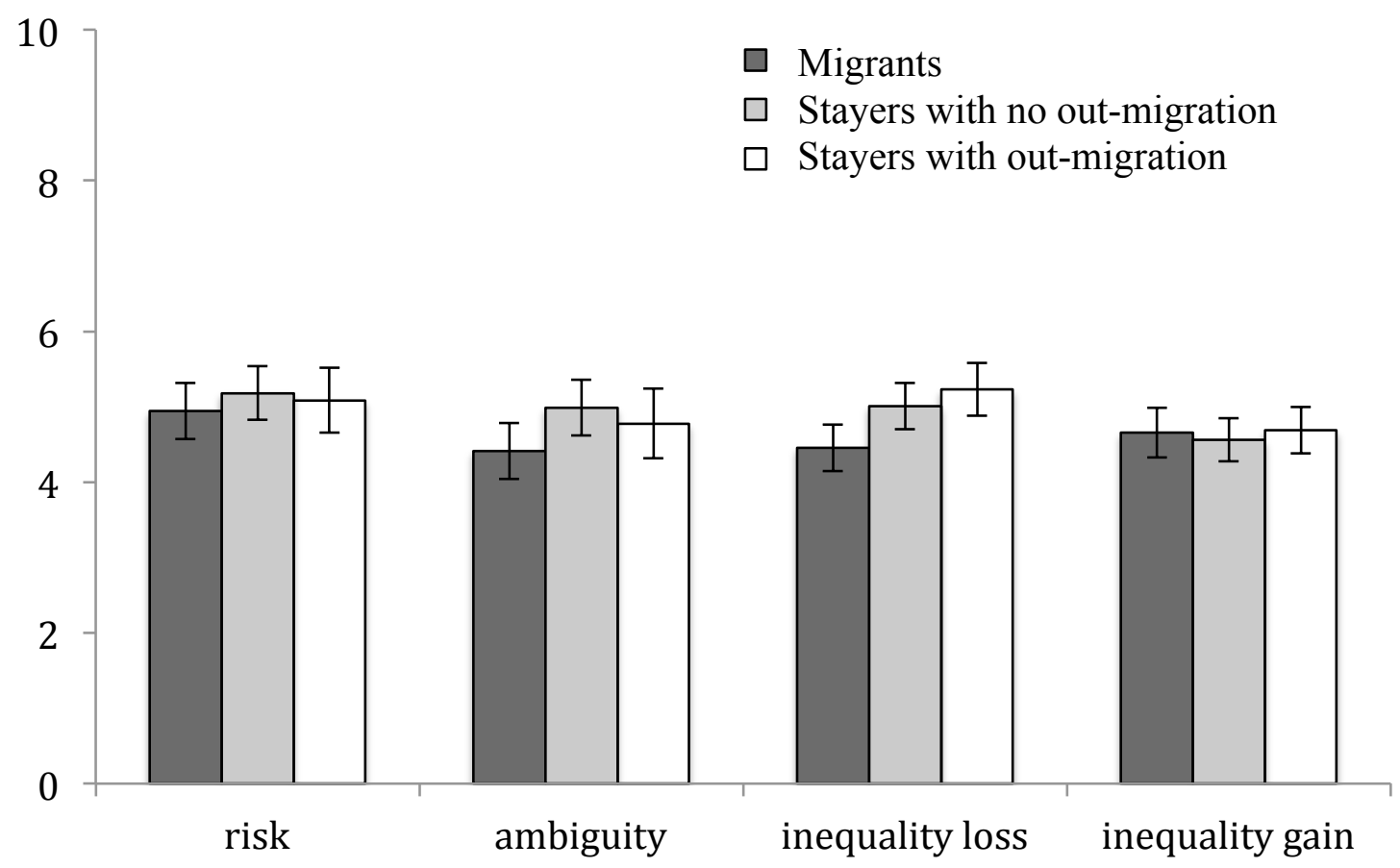




\section{Online Appendix 1. Survey used to qualify participants.}

We thank you for participating in this survey that may allow you to participate in an experiment. This experiment is part of an international research program on risk. Not all of you will be able to participate in the experiment but you have a great chance to be invited.

Please take some time to answer the following questions honestly. Your answers will only be used in research and will be kept anonymously and confidentially for the sole use of the researchers conducting this survey. They will not be communicated to anybody outside the research investigators. None of your answers in this survey will be associated with your performance in the following games if you are chosen to be a participant in the games.

\section{Local Address}

Province___ City___ District (County)___ Street

Family Address

Province___ City (County)___ District (Town)___ Street (Village)

2. Family name___ Given name

3. Cell Phone___ Fixed-line Telephone

4. Year of birth

5. Gender___ (Male/Female)

6. Attained Highest Education Level
A. Illiterate
B. Junior School
C. Middle School
D. High School
E. Vocational Secondary School
F. Junior College
G. Bachelor Degree or more (Master Degree, PhD)

7. Nationality

8. Marital status_____ (Married/Single)

9. How many children do you have?

10. Do you have close relatives (parents, children, uncles or taunts, nephews or nieces) who left their county to work or run business in another county?
A. Yes
B. No

If your answer is yes, how many people left their county to work or run business in another county?

11. Do you personally know neighbors who left this county to work or run business in another county?
A. Yes
B. No

12. Have you ever worked or run business in another county?
A. Yes
B. No

If your answer is yes, please answer the following questions.

13. How long in total have you worked or run business in other county in the past 10 years?

years___ months. 
14. How long have you worked or run business in other county in 2009 ?

months (input 0 if you stayed in this county all along the year 2009).

15 . Where did you work or run business outside this county the last time?

16 . Why did you leave your hometown?
A. It is difficult to find a job in hometown
B. To increase the household income
C. To learn new skills
D. Parents or friends advised me to work outside
E. Other reason, please write it down

Thank you for your answers! 


\section{Online Appendix 2. Instructions (translated into and from Chinese)}

We thank you for participating in this experiment that is part of an international research program on risk. During this experiment you can earn a considerable amount of money if you read the instructions carefully.

This experiment consists of 3 parts during which you will make many decisions. During this session, your earnings will be calculated in points with the following conversion rate:

$$
1 \text { point }=1 \mathrm{RMB}
$$

The earnings in points you will make during these parts will be determined only at the end of the session. At the end of the session, these earnings in points you will make in the various parts will be added up, converted into RMB and paid to you in cash and in private.

All your decisions are anonymous and confidential. Your decisions will be communicated only to the researchers involved in this research program.

Throughout the session, you are not allowed to communicate with the other participants. Be aware that if you communicate with others, you will be excluded from the session and from the payments.

If at any stage, you have any question, please raise your hand and research assistants will answer your questions.

\section{Part One}

On the attached form, we will present you successively with two urns that contain each ten balls, either white or blank. The urn X contains 10 balls: 5 white balls and 5 black balls. The urn Y contains 10 balls, both white and black balls, but you do not know the proportion of balls of each color.

For each urn, you must make 10 successive choices between extracting a ball from the urn with replacement (there are always 10 balls in the urn) or earning a certain amount of money. If you decide to draw a ball from the urn and you extract a black ball, you earn 10 points; if you extract a white ball, you earn 0 point. The 10 certain amounts will vary between 1 point and 10 points. Only one of these twenty decisions for two urns will matter for determining your earnings in this part, as explained below.

Please indicate on the attached form for each proposed choice if you prefer receiving the certain amount or extracting a ball from the urn.

\section{How do we determine your earnings in this part?}

At the end of the session, you are requested to flip a coin to determine which urn will be actually used to determine your earnings (either the urn X or the urn Y). If the side has a tail on it, the urn X (with 5 black balls and 5 white balls) will be used. If the side has a head on it, the urn Y (with unknown number of black and white balls) will be used.

Next, for this urn, you will randomly draw a number between 1 and 10 to determine which of your 10 decisions will matter for determining your earnings.

For this decision, if you have ticked "I choose the certain amount", you will earn this amount. If you have chosen to extract a ball from the urn, you will extract the ball from the selected urn. If you extract a black ball, 10 points will be added to your other earnings from the experiment. If you extract a white ball, you earn nothing.

Consider a first example. Imagine that decision 4 in the urn $\mathrm{X}$ is selected: 


\begin{tabular}{|c|c|c|}
\hline Decision & Option A & Option B \\
& & Urn X \\
& & 10
\end{tabular}

For this decision, suppose you have chosen option A. You will earn 4 points for sure.

Consider a second example. Imagine that decision 8 in the urn $\mathrm{X}$ is selected.

\begin{tabular}{|c|c|c|}
\hline Decision & Option A & Option B \\
& & Urn X \\
& & 10
\end{tabular}

Suppose that for this decision, you chose option B. You will draw one ball from urn X. If the ball color indicates black, you earn 10 points. If the ball color indicates white, you earn 0 point.

Consider a third example. Imagine that the urn $\mathrm{Y}$ is selected and decision 6 is selected.

\begin{tabular}{|l|c|c|}
\hline Decision & Option A & Option B \\
Number & Urn Y \\
& & \\
\hline Decision 6 & $\square$ I choose to earn the certain \\
& $\begin{array}{c}\text { amount of 6 points } \\
\text { a choose to extract a ball from } \\
\text { urn Y }\end{array}$ \\
\hline
\end{tabular}

Suppose that for this decision, you chose option B. You will draw one ball. If the ball color indicates black, you earn 10 points. If the ball color indicates white, you earn 0 points.

If you have any question, please raise your hand and we will answer your question in private.

\section{Part Two}

In this part, we form groups of two players, player $\mathrm{X}$ and player $\mathrm{Y}$. Your earnings or losses depend on your decision or on the decision of another person and on a random draw.

You will make 16 successive decisions in the role of player X. In each decision, player X must choose a payoff distribution between himself and player Y. Player Y can only accept the payoff chosen by player $\mathrm{X}$. 
For each of the 16 decisions, you have to choose privately between option A (left column) or option B (right column). Every decision will have an equal chance to be chosen for actual payment at the end of the session, so you should make every decision seriously.

At the end of the session, we will match you with another person in this room. You will never be informed on the identity of the other person. Next, we will randomly draw your role and that of the other person such that there is one player $\mathrm{X}$ and one player $\mathrm{Y}$ in each pair.

Next, you will randomly draw a number between 1 and 16 to determine which of your 16 decisions will matter for determining your earnings or loss.

If you have been assigned the role of player X, you earn or lose the amount you have chosen for yourself in that decision. If you are assigned the role of player $\mathrm{Y}$, you earn or lose the amount that player $\mathrm{X}$ with whom you are paired has chosen for person $\mathrm{Y}$ in this decision.

Consider a first example. Imagine that you have been assigned the role of player $\mathrm{Y}$ and that decision 3 is selected.

\begin{tabular}{|c|c|}
\hline \multicolumn{1}{|c|}{ Option A } & \multicolumn{1}{|c|}{ Option B } \\
Player X earns 3 and & Player X earns 8 and \\
Player Y earns 3 & Player Y earns 2 \\
$\square$ I choose option A & $\square$ I choose option B \\
\hline
\end{tabular}

If the player $\mathrm{X}$ has chosen option $\mathrm{A}$, he/she earns 3 points and you earn 3 points. If the player $\mathrm{X}$ has chosen option $\mathrm{B}$, he or she earns 8 points and you earn 2 points.

Consider a second example. Imagine that you have been assigned the role of player $\mathrm{X}$ and that decision 6 is selected.

\begin{tabular}{|l|l|}
\hline \multicolumn{1}{|c|}{ Option A } & \multicolumn{1}{c|}{ Option B } \\
Player X earns 6 and & Player X earns 8 and \\
Player Y earns 6 & Player Y earns 2 \\
$\square$ I choose option A & $\square$ I choose option B \\
\hline
\end{tabular}

If you have chosen option A, you earn 6 points and player $Y$ earns 6 points. If you have chosen option $\mathrm{B}$, you earn 8 points and player $\mathrm{Y}$ earns 2 points.

Consider a third example. Imagine that you have been assigned the role of player $\mathrm{X}$ and that decision 12 is selected.

\begin{tabular}{|c|c|}
\hline \multicolumn{1}{|c|}{ Option A } & Option B \\
Player X earns - 4 and & Player X earns -2 and \\
Player Y earns -4 & Player Y earns -8 \\
$\square$ I choose option A & $\square$ I choose option B \\
\hline
\end{tabular}

If you have chosen option A, you lose 4 points and player Y loses 4 points. If you have chosen option B, you lose 2 points and player $\mathrm{Y}$ loses 8 points.

Consider a fourth example. Imagine that you have been assigned the role of player $\mathrm{Y}$ and that decision 16 is selected. 


\begin{tabular}{|c|c|}
\hline \multicolumn{1}{|c|}{ Option A } & Option B \\
Player X earns -8 and & Player X earns -2 and \\
Player Y earns -8 & Player Y earns -8 \\
$\square$ I choose option A & $\square$ I choose option B \\
\end{tabular}

If the player $\mathrm{X}$ has chosen option $\mathrm{A}$, he/she loses 8 points and you lose 8 points. If the player $\mathrm{X}$ has chosen option $\mathrm{B}$, he or she loses 2 points and you lose 8 points.

If you have any question, please raise your hand and we will answer your questions in private. Any communication between participants is forbidden throughout the experiment.

\section{Part Three}

In this part, there will be 3 sub-parts including totally 12 trials and the three sub-parts will be run one by one. Every sub-part involves a series of decisions about whether or not to go fishing. After completion of the whole session, one of the 12 trials will be randomly chosen for true payment.

There are eight trials in the first sub-part. You receive an initial endowment of 6 points in every decision. In all of the eight trials in this sub-part, we will announce a number $\mathrm{C}$. $\mathrm{C}$ is the capacity of the pond, i.e. the number of anglers who can catch fish. For example, if $\mathrm{C}=3$, then the 3 highest-rank entrants will be successful (earn points) and lower-ranked entrants will be unsuccessful (lose points). In all of the eight decisions, the successful entrants earn some points and the unsuccessful entrants lose some points.

In each decision, your task is you decide simultaneously with other participants if you go fishing in the pond. In the eight trials, if you do not go fishing, then you earn nothing and lose nothing. Therefore, if you want to guarantee that you will lose nothing, simply do not go fishing. If you go fishing, then your payoff in points is determined by the payoff table shown on each form, and by your rank relative to the ranks of the other participants who decided to go fishing as you (as explained below).

In each trial, we will distribute one sheet indicating the capacity of the pond for the current trial and a payoff table. First, we ask you to estimate how many of the 11 other participants in this session (excluding you) you expect will go fishing in the pond. Next, you will indicate whether you decide to go fishing, by checking the appropriate box.

The following table gives you an example of the payoff table in a trial.

For example, suppose $\mathrm{C}$ (capacity of the pond) $=4$ and your initial endowment is 6 points:

\begin{tabular}{|c|c|}
\hline & \\
& \\
& Pond Capacity $=4$ \\
\hline Rank Level & Payoff \\
\hline 1 & \\
\hline 2 & \\
\hline 3 & \\
\hline 4 & \\
\hline 5 & \\
\hline 6 & \\
\hline
\end{tabular}

In the four rows above, payoffs are positive; in the remaining rows below, payoffs are always -6 points. 


\begin{tabular}{|c|c|}
\hline 7 & \\
\hline 8 & 0 \\
\hline 9 & 0 \\
\hline 10 & 0 \\
\hline 11 & 0 \\
\hline 12 & 0 \\
\hline
\end{tabular}

Please indicate the number of other participants you believe will choose to enter (a number between 0 and 11)

Please indicate your decision: $\square$ I enter $\square$ I stay out

Suppose that you have decided to go fishing in the pond. If you are the first highest-ranked among those participants who have decided to go fishing in pond, you earn 18 points. You earn 12 points if you are ranked second. You earn 4 points if you are ranked third; you earn 2 points if you are ranked fourth. If you are ranked fifth or more, you lose 6 points.

\section{How is your rank determined?}

Your rank is determined as follows. At the end of this session, if this trial is chosen for actual payment, we will prepare messages indicating the id number of participants who chose to enter and we will randomly assign messages to ranks. If the message indicating your id number is chosen first, you are assigned the highest rank; if the message indicating your id number is chosen secondly, you are assigned the second highest rank. Like this, you will be assigned the lowest rank if the message indicating your id number is chosen lastly.

\section{How is your payoff determined in this part?}

At the end of the session, we will put 12 messages representing 12 trials in the three sub-parts, numbered from 1 to 12, in a bag. We will extract one message from the bag. Its number will indicate the number of the trial that will be paid. Because every trial has an equal chance of being chosen for payment, you should make every decision seriously.

In the trial that is chosen for actual payment, we determine your payoff as follows.

- If your prediction for the number of participants who go fishing in the pond is correct, you earn 2 points.

- We will calculate the number of participants who go fishing in the pond in this trial. If you have decided to go fishing in the pond, we determine your rank relative to the rank of the other participants who have chosen to fish as you. If your rank is less than or equal to the pond capacity, C, you earn points accordingly. If your rank level is more than the market capacity, C, you will lose points accordingly.

- Your total payoff is the sum of your initial endowment in this trial + your earnings for your correct predictions + the points earned from your fishing decision /or/ - the points lost from your fishing decision in this trial.

If you have any question, please raise your hand and we will answer your questions in private. Any communication between participants is forbidden throughout the experiment. 


\section{Online Appendix 3. Tables}

Table A1: Proportion of multiple switchers, pairwise comparison tests

\begin{tabular}{lccc}
\hline Preferences & $\begin{array}{l}\text { Migrants vs. Stayers } \\
\text { with no out- } \\
\text { migration }\end{array}$ & $\begin{array}{l}\text { Migrants vs. Stayers } \\
\text { with out-migration }\end{array}$ & $\begin{array}{l}\text { Stayers with no out- } \\
\text { migration } v s . \text { Stayers } \\
\text { with out-migration }\end{array}$ \\
\hline Risk & 0.816 & 0.368 & 0.259 \\
Ambiguity & 0.492 & 0.826 & 0.368 \\
\hline Note: These values are $p$-values from pairwise proportion tests. $* *$ indicates significance at the $5 \%$ level.
\end{tabular}

Table A2: Mean attitudes towards risk, ambiguity and inequality in the domain of gains and the domain of losses, pairwise comparison tests

\begin{tabular}{lccc}
\hline Preferences & $\begin{array}{l}\text { Migrants vs. Stayers } \\
\text { with no out-migration }\end{array}$ & $\begin{array}{l}\text { Migrants vs. Stayers } \\
\text { with out-migration }\end{array}$ & $\begin{array}{l}\text { Stayers with no out- } \\
\text { migration } v s . \text { Stayers } \\
\text { with out-migration }\end{array}$ \\
\hline Risk & 0.647 & 0.809 & 0.862 \\
Ambiguity & 0.272 & 0.541 & 0.721 \\
$\begin{array}{l}\text { Inequality } \\
\text { Gain domain }\end{array}$ & 0.210 & 0.103 & 0.640 \\
\multicolumn{1}{c}{ Loss domain } & 0.834 & 0.943 & 0.769 \\
\hline
\end{tabular}

Note: These values are $p$-values from pairwise mean-comparison tests. 
Table A3: Determinants of the Probability of Entry, Competitiveness and Predicted Competitiveness of Others in the Market Entry Game under Limited Number of Prizes

\begin{tabular}{|c|c|c|c|c|c|c|}
\hline & \multicolumn{2}{|c|}{ Entry } & \multicolumn{2}{|c|}{ Competitiveness } & \multicolumn{2}{|c|}{$\begin{array}{c}\text { Predicted Competitiveness of } \\
\text { Others }\end{array}$} \\
\hline & (1) & (2) & (3) & (4) & (5) & (6) \\
\hline \multirow{2}{*}{ Migrant } & 0.149 & $0.174 * *$ & $0.177^{*}$ & $0.165^{* *}$ & $0.212 * *$ & $0.158^{*}$ \\
\hline & $(0.102)$ & $(0.088)$ & $(0.095)$ & $(0.076)$ & $(0.100)$ & $(0.088)$ \\
\hline \multirow{2}{*}{$\begin{array}{l}\text { Stayer w. no } \\
\text { out-migration }\end{array}$} & 0.025 & 0.024 & 0.059 & 0.051 & $0.174 *$ & $0.140^{*}$ \\
\hline & $(0.094)$ & $(0.088)$ & $(0.086)$ & $(0.076)$ & $(0.090)$ & $(0.085)$ \\
\hline \multirow{2}{*}{ Male } & 0.117 & & 0.029 & & 0.027 & \\
\hline & $(0.086)$ & & $(0.079)$ & & $(0.089)$ & \\
\hline \multirow{2}{*}{ Age } & -0.000 & & -0.000 & & -0.001 & \\
\hline & $(0.003)$ & & $(0.003)$ & & $(0.003)$ & \\
\hline \multirow{2}{*}{ Income } & 0.002 & & 0.000 & & -0.002 & \\
\hline & $(0.002)$ & & $(0.001)$ & & $(0.002)$ & \\
\hline \multirow{2}{*}{ East } & -0.042 & & -0.068 & & -0.077 & \\
\hline & $(0.072)$ & & $(0.063)$ & & $(0.073)$ & \\
\hline \multirow{2}{*}{ Risk } & 0.013 & & 0.019 & & $0.034 * *$ & \\
\hline & $(0.014)$ & & $(0.012)$ & & $(0.014)$ & \\
\hline \multirow{2}{*}{$\begin{array}{l}\text { Risk Multi- } \\
\text { switcher }\end{array}$} & $-0.136^{*}$ & & $-0.129 *$ & & 0.013 & \\
\hline & $(0.080)$ & & $(0.077)$ & & $(0.083)$ & \\
\hline Observations & 516 & 520 & 516 & 520 & 516 & 520 \\
\hline Clusters & 129 & 130 & 129 & 130 & 129 & 130 \\
\hline Pseudo $\mathrm{R}^{2}$ & .0635 & .0178 & .0481 & .0207 & .0422 & .0144 \\
\hline
\end{tabular}

Notes: These regressions only consider decisions and beliefs in rounds 1, 3, 5 and 8 of the fishing game where pond capacity $=2$ or 4 . Estimates are from Probit regressions clustered at the individual level, with marginal effects reported as point estimates, and fully robust standard errors reported in parentheses. $*$ is $10 \%$ significance level; $* *$ is $5 \%$, and $* * * 1 \%$. 